\title{
Elizabeth Pérez
}

Religion in the Kitchen: Cooking, Talking, and the Making of Black Atlantic

Traditions. New York: New York University Press, 2016. xi + 298 pp. (Paper

US\$29.00)

"Real Women Pluck Chicken" (p. 105). At least that is what a cook at Ilé Laroye, one of 15 Lucumí house-temples in Chicago in the 20oos, told Elizabeth Pérez after long hours of shared labor. She meant for the words to be printed on an imaginary tee-shirt, but the catchphrase also captures the wry sensibility and provocative arguments at the core of Pérez's ethnography. Arduous enough to merit lamentations, chicken plucking stands for the unheralded work that mostly uninitiated women and gay men perform in Lucumí houses of worship. In addition to detailing the hard-earned knowledge required to slaughter, butcher, cook, and serve proper sacrifices to deities known as orishas, Pérez makes a persuasive case for the centrality of the kitchen to the constitution of initiates into religious subjects and collectivities. According to Pérez, the work and talk around kitchen tables is "the secret recipe" for the reproduction of "Black Atlantic traditions" from Candomblé to Lucumí, a religion known popularly and with some derision as Santería.

Scarcely visible to outsiders, the "micropractices" of the kitchen are "routine and intimate sequences of operations" conducted "at the fringes and in the gaps of ceremonies such as divination sessions, rites of consecration, and drum feasts" (p. 9). Despite their small scale and low visibility, Pérez shows that micropractices give rise to well-defined synaesthetics - tastes, habits, and valued states - and also shape time and space in house-temples. As one might expect after Paul Christopher Johnson's Secrets, Gossip, and the Gods (2002) on Candomblé and Kristina Wirtz's Ritual, Discourse, and Community in Cuban Santería (2007) on reflexive talk in Lucumí communities, kitchen conversation socializes participants while immersing them in religious idioms and signifying systems. Working under the supervision of a senior officiant known as alashé, kitchen attendants learn the correct way to extract and cook iñales, the viscera and extremities of sacrificial animals that must be prepared to the orishas' exacting specifications. They also learn how to serve tables for priests and guests, and how to narrate their paths to initiation in the proper generic forms.

Pérez's more pointed finding is that in performing those tasks, the women and men in the kitchen are essential to the functioning of house-temples, where the work that elders may perform is subject to detailed rules and injunctions. Just as importantly, Pérez argues that it is in the kitchen that newcomers are "seasoned" and begin striving to become proper religious subjects. The prominence of women and gay men among cooks is not coincidental.

(C) REINALDO L. ROMÁN, 2018 | DOI: 10.1163/22134360-09201035

This is an open access article distributed under the terms of the prevailing CC-BY-NC license at the time of publication. 
In Lucumí, female bodies are portrayed as "the most receptive material container for the gods' sacred power" (p. 114). Gay men are depicted as analogous to women in their suitability as "mounts" or possession priests. It is not an accident, then, that new priests are called iyawo, Yoruba for "bride, especially wife younger than the speaker," during the year that follows initiation (p. 266). According to Pérez, "Women's domestic careers as wives and mothers form the basis for conceptualizing the proper relationship between people and gods" (p. 114).

Pérez's analysis of induction into Lucumí communities challenges functionalist assumptions about how and why initiations occur. Few of Ilé Laroye's members were born into the tradition. Most, including Ashabi Mosely, the senior priest who heads Ilé Laroye, are African Americans who could be called converts despite earlier engagements with African-derived religions, Catholicism, and the Black Spiritual Church. As Pérez describes them, initiations are not purpose-driven efforts to satisfy individual needs. Although practitioners find Lucumís connection to Africa desirable, initiations do not assure prosperity, deliver freedom from toil, or offer a reprieve from racism. Initiates underscore their reluctance to shoulder the burden of serving the orishas, but recount that poor health, misfortune, and the orishas' demands overcame their reticence. The trials and labor required to join Lucumí communities may be seen as "translations" into "ritual disciplines" of the ordeals associated with enslavement and seasoning. Pérez speculates that ritualizing of this sort "allowed priests of African descent to pass on counter-memories of enslavement to succeeding generations" that included phenotypically white, Asian, and indigenous initiates (p. 109). Although Pérez is careful to differentiate between translation and recapitulation, her interpretation could use further probing and historicizing.

Aimed at advanced students, Religion in the Kitchen is nevertheless a pleasure to read. The lucid writing is as notable for the analyses that it pursues as for the polemics that it sidesteps. While Pérez does comment on long-running debates surrounding retention, creolization, accommodation, and resistance, she largely avoids extended inquiries into the origins and evolution of Lucumí across the Atlantic to open up new lines of sight. Above all, she illuminates the spaces in the back of the house, where so much of the crucial work of making food and making family takes place.

\section{Reinaldo L. Román}

Department of History, University of Georgia rroman@uga.edu 